\title{
Teachers' Perception about Students Indulging in Deviant Behaviour
}

\author{
Bhargavi Jayaram $^{1 *}$, Mr. Don Caeiro ${ }^{2}$
}

\section{ABSTRACT}

Deviant behaviour is a behaviour that violates the rules, understanding, or expectations of social system. This kind of deviant behaviour is mostly seen in school students. Therefore a study was conducted in order to find out the causes of deviant behaviour among students, its effects and ways to combat them. Since school students are more frequently around teachers of the school the information pertaining to this study was collected from the school teachers. For the purpose of this study an open ended interview schedule was prepared and data was collected from 50 school teachers. According to the study conducted $96 \%$ of the respondents sate that school students will indulge in deviant behaviour. According to the teachers the mostly seen deviant behaviours are disobeying elders, stealing, bunking classes, drug abuse etc. and this behaviour will show a great impact on their studies. This impact is either in the form of failure in the studies, they may drop out of school; they can seclude themselves from the other classmates, etc. They will start failing in exams and sometimes they might even dropout from school. From my study it was found that $40 \%$ of the students get in deviant behaviour due to improper parenting style, $26 \%$ due to family background, $22 \%$ of the students gets influenced by the media and the remaining $12 \%$ is due to friends circle and surrounding. This kind of deviant behaviour can be prevented by showing more love and care from parents and teachers, society should treat them equally instead of punishing them.

Keywords: Deviant, Crime

Impact of crime, and the criminals involved in the crime. Criminologists study criminology in an attempt to better understand what motivates the criminal to act in a criminal manner. Their work is generally focused on the study of:

1. Theories explaining illegal and/or deviant behavior

2. The social reaction to crime

\footnotetext{
${ }^{1}$ B.Sc. Forensic Science, Department of Forensic Science, Jain University, Bangalore, India

${ }^{2}$ Assistant professor, Department of Forensic Science, Jain University, Bangalore, India

*Responding Author
}

Received: February 7, 2017; Revision Received: March 6, 2017; Accepted: March 10, 2017

(C) 2017 Jayaam B, Caeiro D; licensee IJIP. This is an Open Access Research distributed under the terms of the Creative Commons Attribution License (www.creativecommons.org/licenses/by/2.0), which permits unrestricted use, distribution, and reproduction in any Medium, provided the original work is properly cited. 
3. The political terrain of social control

4. The effectiveness of anti-crime policies

5. Criminals

6. Crimes

7. Crime victims

\section{Relationship between Crime \& Deviance}

The sociology of crime and deviance is the study of the making, breaking, and enforcing of criminal laws and social norms. Its aim is to understand empirically and to develop and test theories explaining criminal and deviant behavior, the formation and enforcement of laws, and the operation of criminal processing systems.

To a large extent, criminology and studies of deviance have developed along separate tracks although they show much overlap. Criminologists have typically limited themselves to issues about legality, crime, or crime-related phenomena. Students of deviance, on the other hand, have studied crime as well as a wider range of behaviors or conditions that are deviant by one or another of the definitions reviewed but are not necessarily illegal, such as suicide, alcoholism, homosexuality, mentally disordered behaviors, stuttering, and even such behaviors as public nose picking or flatulence, sectarian religious behaviors, and body mutilation. Hence, it is difficult to distinguish criminology clearly from studies of deviance.

\section{Deviant Behavior in School children}

Deviant behaviour is a behaviour that violates the rules, understandings, or expectations of social systems. Normative rules are inherent in the nature of all social systems, whether they bad friendship groups, engaged couples, families, work teams, factories or national societies. Deviant behaviour may also be defined as socially disvalued behaviour .This definition includes mental retardation, blindness, ugliness, other physical defects and handicaps, illness of all sorts and shameful past.

Behaviour is seen as deviant when people are alarmed, angered, outraged or threatened by violation of what they consider right and proper. Now a day's schools are helpless regarding students with deviant behaviour and the educational authority does not have effective measures in place to deal with these problems. Some teachers attribute the above problems to teachers lacking the right to use physical punishment, as it is forbidden in the current educational regulations. In addition physical punishment violates student's surface behaviour. Changing a student is core temperament is effective measure to improve student behaviour. Deviant behaviour includes skipping class, unauthorized smoking, use of drugs, school vandalism, and stealing. Sometimes it is seen that very few students skipped class, and that peers would not report students who did. Smoking restrictions will be violated by all students who smoke. Few students use alcohol which is a deviant behaviour. However, stealing personal property angered students and they reported they would prosecute someone who took their property. Students do 
not disapprove of deviant behaviour unless it directly affects them. Students identified the major cause of deviant behaviour as lack of parental control over their children.

\section{Factors that cause deviant behaviour}

1. Family background

2. Parenting style

3. Uninvolved parenting

4. Social factors

5. Peer influence

6. Economic factors

7. Drug abuse

8. Media

\section{Parenting Style}

Students who come from abusive parents also display characteristics of abusive persons. Such children for instance end up beating their fellow playmates without feeling any kind of remorse. On the other hand, students brought up by uncaring parents usually portray delinquent behaviours. They resort to criminal activities to achieve what they could not get from their parents. Such students take part in criminal activities such as stealing, rioting/rebellion among others. The society also models the behaviour of people.

The attitudes that other people have concerning their fellow human race lead to rebellion from the marginalized group. Such people who are neglected by the society, and whose needs are not looked into by the people in authority end up engaging in activities or behaviour that contradicts the requirements of the society.

\section{What are some positives/advantages of corporal punishment?}

Corporal punishment may be divided into three main types:

1. Parental or domestic corporal punishment: within the family, children punished by parents or guardians;

2. School corporal punishment: within schools, when students are punished by teachers or school administrators;

3. Judicial corporal punishment: as part of a criminal sentence ordered by a court of law. Closely related is prison corporal punishment, ordered either directly by the prison authorities or by a visiting court.

\section{REVIEW OF LITERATURE}

A study was conducted on-Perceived factors influcing deviant behavior children in Njathaini Community Nairobi, Kenya by Mbuthia Winnie Wairimu December 2013. The Study was made because the children are often faced by a number of challenges that are unique. These challenges differ between developed and developing countries, with the latter facing rapid urbanization that 
does not match government investments in social infrastructure. Irrespective of this, the challenges predispose the children to involvement in delinquencies the so called deviant behavior.

A study was conducted on the deviant behavior of secondary students. A study made by University of Hong Kong by Lee Yeyk Chi August 1994. In this study, the method of one-shot study has been used to understand the deviant behavior of secondary school students.

A similar study was conducted on-Teacher Perceptions of Behavior Problems in Small and Large Schools by Ruth E.Martin, PH.D ,Patricia Walford Kramer and Harriet K. Light, PH.D. In this study a total of 144teachers from rural and urban schools in a Midwestern state responded to open-ended questions related to students' behavior problems. Differences between students from rural and urban schools are described in the areas of serious behavior problems, handling behavior problems, and eliminating behavior problem.

\section{METHODOLOGY}

Methodology is the systematic, theoretical analysis of the methods applied to a field of study. It comprises the theoretical analysis of the body of methods and principles associates with a branch of knowledge .Typically; it encompasses concepts such as paradigm, theoretical model, phases and quantative or qualitative techniques. The Methodology is the general research strategy that outlines the way in which is the research project is to be undertaken and ,among other things ,identifies the methods to be used in it.

\section{Aim and Objectives of the study}

1. To find out the opinion of teachers' on deviant behaviour among students.

2. To find out teachers' perspective of the effect of deviant behaviour among students.

3. To find out what strategies and methods can be implemented at various levels in order to control and prevent such deviant behaviour.

\section{Sample}

For this study, a total sample of fifty individuals was chosen. The method of sampling used was random sampling. The random sampling method used was purposive sampling. Teachers of three different schools were chosen for the purpose of this study.

\section{Procedure}

For the purpose of this study, an open-ended interview schedule was designed the interview schedule was divided into four different parts. The first part consisted of personal details about the teacher/respondent like age, qualification, years of experience etc. The second part of the interview schedule consisted of seven questions which concentrated on the general opinion of deviant behaviour among students. The next part consisted of six questions which related to their 
perception on the effects of deviant behaviour. The last part was about the prevention of deviant behaviour and related information comprising of five questions.

A pilot study was conducted on ten teachers in order to check the interview schedule for flaws and to see if there is anything missing in the interview schedule. The interview schedule was first conducted and after analyzing the answers; the interview schedule was reframed by adding few questions, by combing few questions and by removing few questions.

After the interview schedule was reworked it was subjected to the samples chosen. The interview schedule for fifty teachers was conducted and data was collected. The interview was made in person. The questions were asked to the teacher and the replies/answers given by the teachers were recorded onto the interview schedule simultaneously. A code book was prepared in order to segregate the data and make the tabulations. This was achieved by tallying the questions and answers for that particular question with respect to the respondents. The data tallied is then put into tables and further analysis was done. After the tabulation of this data some important data was also depicted using charts and graphs.

\section{Limitations}

1. The study can be conducted on the specified teaching experience.

\section{OBSERVATION AND ANALYSIS}

Table No. 1: Showing whether deviant behavior is seen in school students.

\begin{tabular}{|c|c|c|c|}
\hline Sl.no & $\begin{array}{c}\text { Is deviant behavior observed among } \\
\text { school students? }\end{array}$ & No. of Respondents & Percentage \\
\hline 1 & Yes & 48 & $96 \%$ \\
\hline 2 & No & 2 & $4 \%$ \\
\hline \multicolumn{2}{r|}{ Total } & 50 & 100 \\
\hline
\end{tabular}

According to the above table, 96\% of the teachers told that deviant behavior is seen among the school students and $4 \%$ of teachers told that deviant behavior is not seen.

Table No. 2: Showing the distribution of stages at which deviant behavior was observed.

\begin{tabular}{|c|c|c|c|}
\hline Sl.no & Age(Years) & No. of Respondents & Percentage \\
\hline 1 & $8-12$ & 6 & $12 \%$ \\
\hline 2 & $12-15$ & 38 & $76 \%$ \\
\hline 3 & $15-17$ & 6 & $12 \%$ \\
\hline & Total & 50 & 100 \\
\hline
\end{tabular}

According to the above table deviant behavior is usually seen among the age group of 12-15 years, $76 \%$ and from $15-17$ years and $8-12$ years is $12 \%$ respectively. 
Teachers' Perception about Students Indulging in Deviant Behaviour

Table No. 3: Showing the distribution of deviant activities seen among students.

\begin{tabular}{|c|l|c|c|}
\hline Sl.no & Deviant activities & No. of Respondents & Percentage \\
\hline 1 & Stealing & 10 & $20 \%$ \\
\hline 2 & Drug abuse & 6 & $12 \%$ \\
\hline 3 & Disobeying elders & 14 & $28 \%$ \\
\hline 4 & Lying & 9 & $18 \%$ \\
\hline 5 & Bunking class & 3 & $6 \%$ \\
\hline 6 & Fighting & 8 & $16 \%$ \\
\hline & Total & 50 & 100 \\
\hline
\end{tabular}

According to the above table the most seen deviant behavior is disobeying elders $28 \%$ among the population stealing, lying, fighting, drug abuse, bunking classes-20\%, 18\%, 16\%, 12\% 6\% respectively.

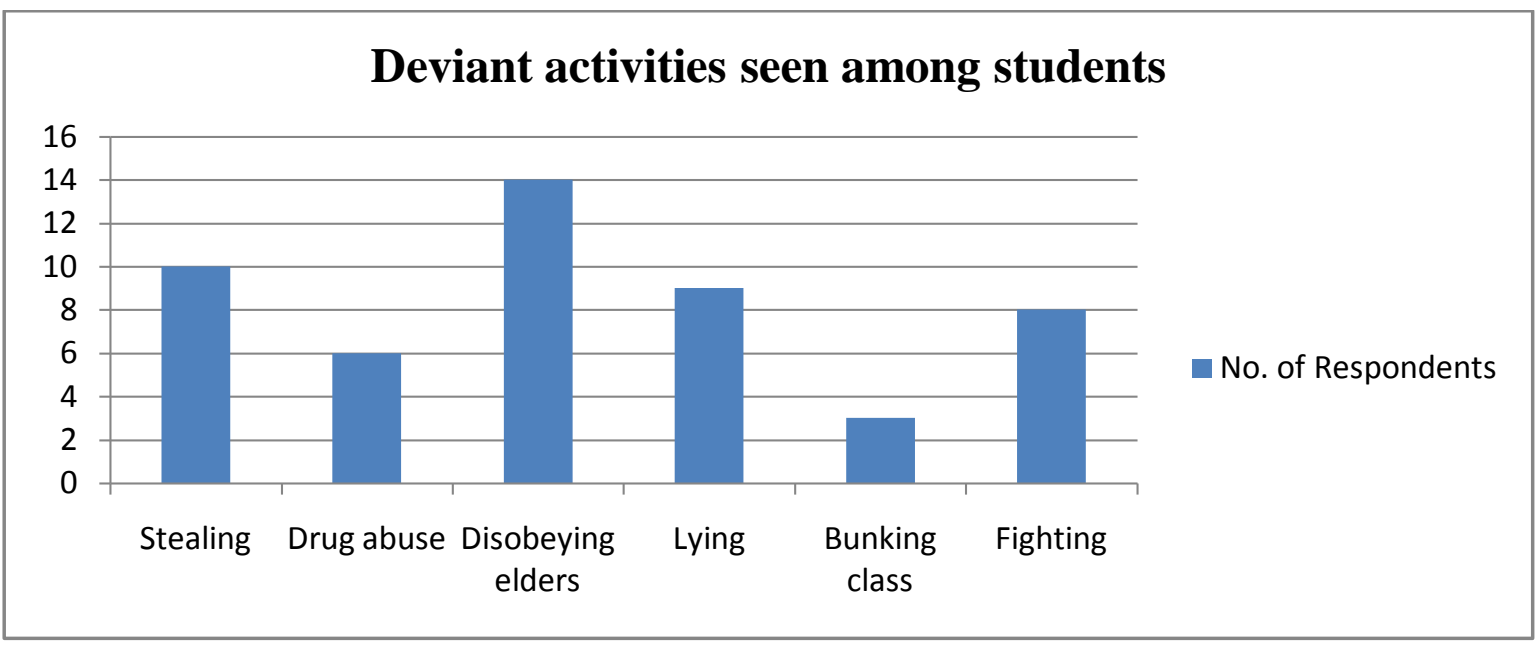

Table No.4: Showing the distribution for factors of deviant behavior.

\begin{tabular}{|c|l|c|c|}
\hline Sl.no & Factors & No. of Respondents & Percentage \\
\hline 1 & Parenting style & 20 & $40 \%$ \\
\hline 2 & Family background & 13 & $26 \%$ \\
\hline 3 & Friends circle and surrounding & 6 & $12 \%$ \\
\hline 4 & Media & 11 & $22 \%$ \\
\hline & Total & 50 & 100 \\
\hline
\end{tabular}

According to the above table the main factor for deviant behavior is neglected parenting style $40 \%$ among the population, $26 \%$ is family background, $22 \%$ and $12 \%$ is media and friends circle respectively. 
Teachers' Perception about Students Indulging in Deviant Behaviour

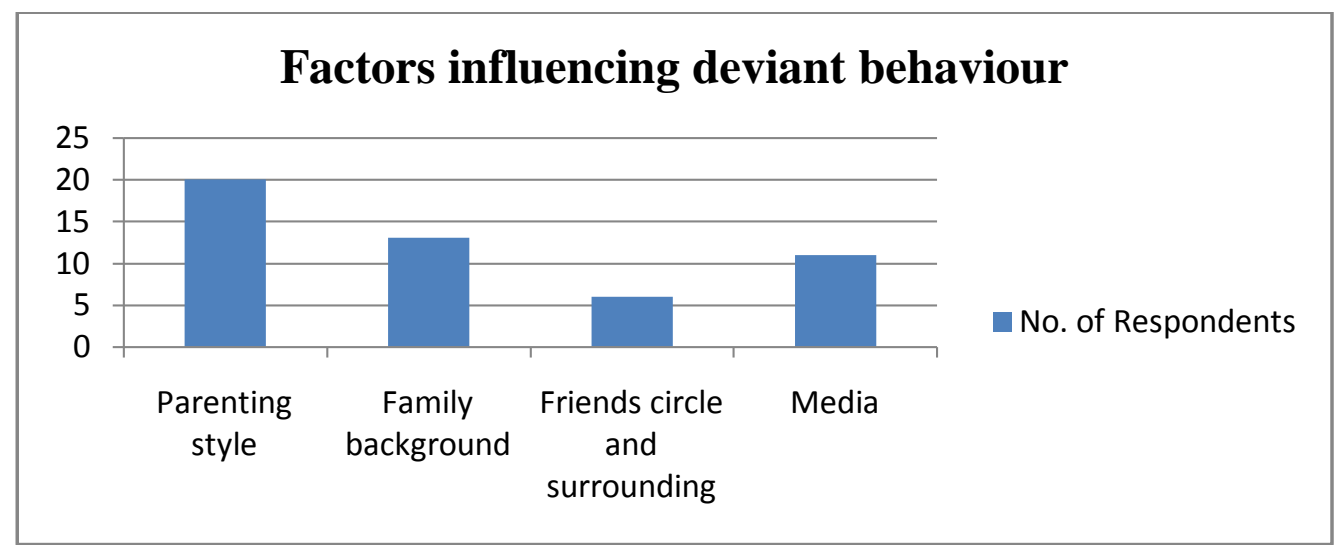

Table No.5: Showing the distribution for personal effects on the student.

\begin{tabular}{|c|l|c|c|}
\hline Sl.no & Personal effects & No. of Respondents & Percentage \\
\hline 1 & Distractions & 24 & $48 \%$ \\
\hline 2 & Antisocial activities & 5 & $10 \%$ \\
\hline 3 & Inferiority complex & 4 & $8 \%$ \\
\hline 4 & Troubling teachers & 1 & $2 \%$ \\
\hline 5 & Affects the behavior & 3 & $6 \%$ \\
\hline 6 & No goal in life & 13 & $26 \%$ \\
\hline & Total & 50 & 100 \\
\hline
\end{tabular}

According to the above table $48 \%$ of students will get distracted, $10 \%$ of students will indulge in antisocial activities, 26\% of students won't have any goal in life and $8 \%$ of students will have inferiority complex.

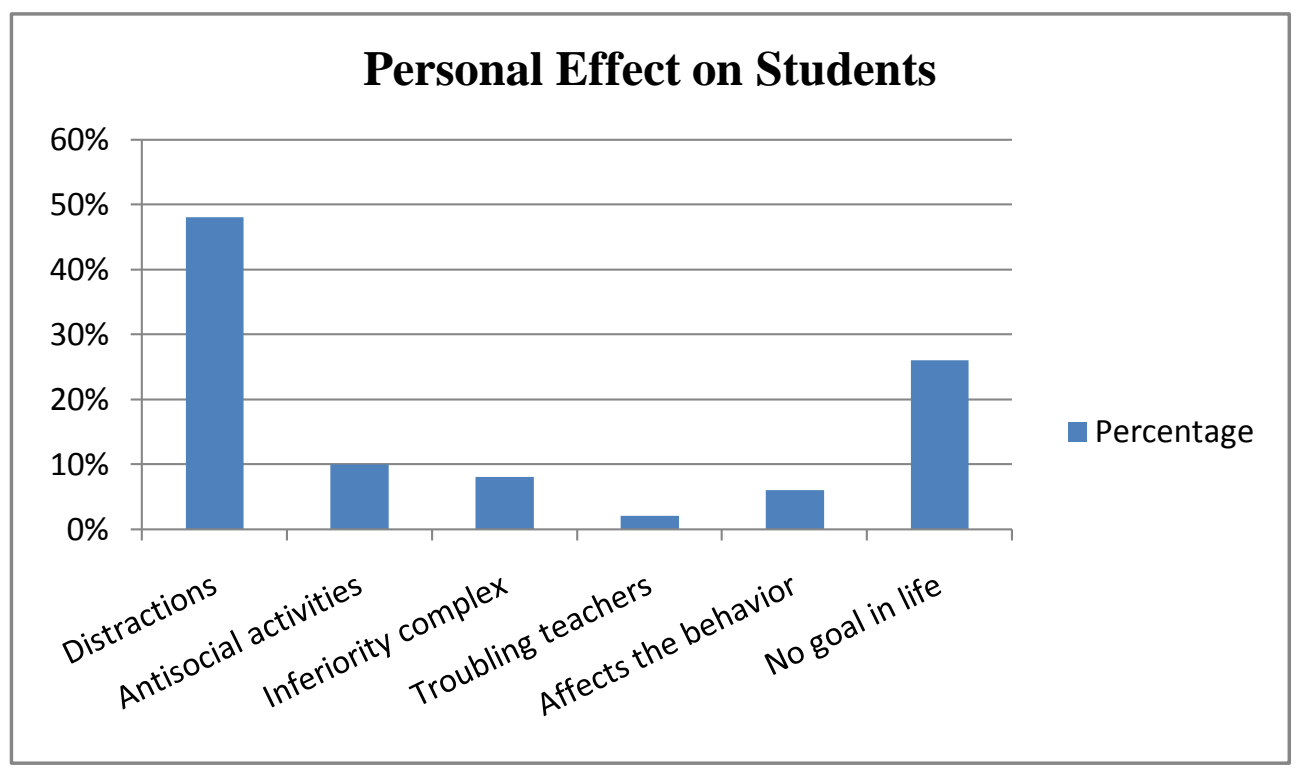


Teachers' Perception about Students Indulging in Deviant Behaviour

Table No.6: Showing the distribution of social behavior of deviant students.

\begin{tabular}{|c|l|c|c|}
\hline Sl.no & Social behavior & No. of Respondents & Percentage \\
\hline 1 & No social activities & 9 & $18 \%$ \\
\hline 2 & Might go to depression & 3 & $6 \%$ \\
\hline 3 & Ego ,Arrogant & 3 & $6 \%$ \\
\hline 4 & Lack of interaction & 35 & $70 \%$ \\
\hline$\quad$ Total & 50 & 100 \\
\hline
\end{tabular}

According to the above table $70 \%$ of the students among the population will have lack of interaction with others, $18 \%$ of students won't get into any kind of social activities $6 \%$ of students might become arrogant and even go to depression.

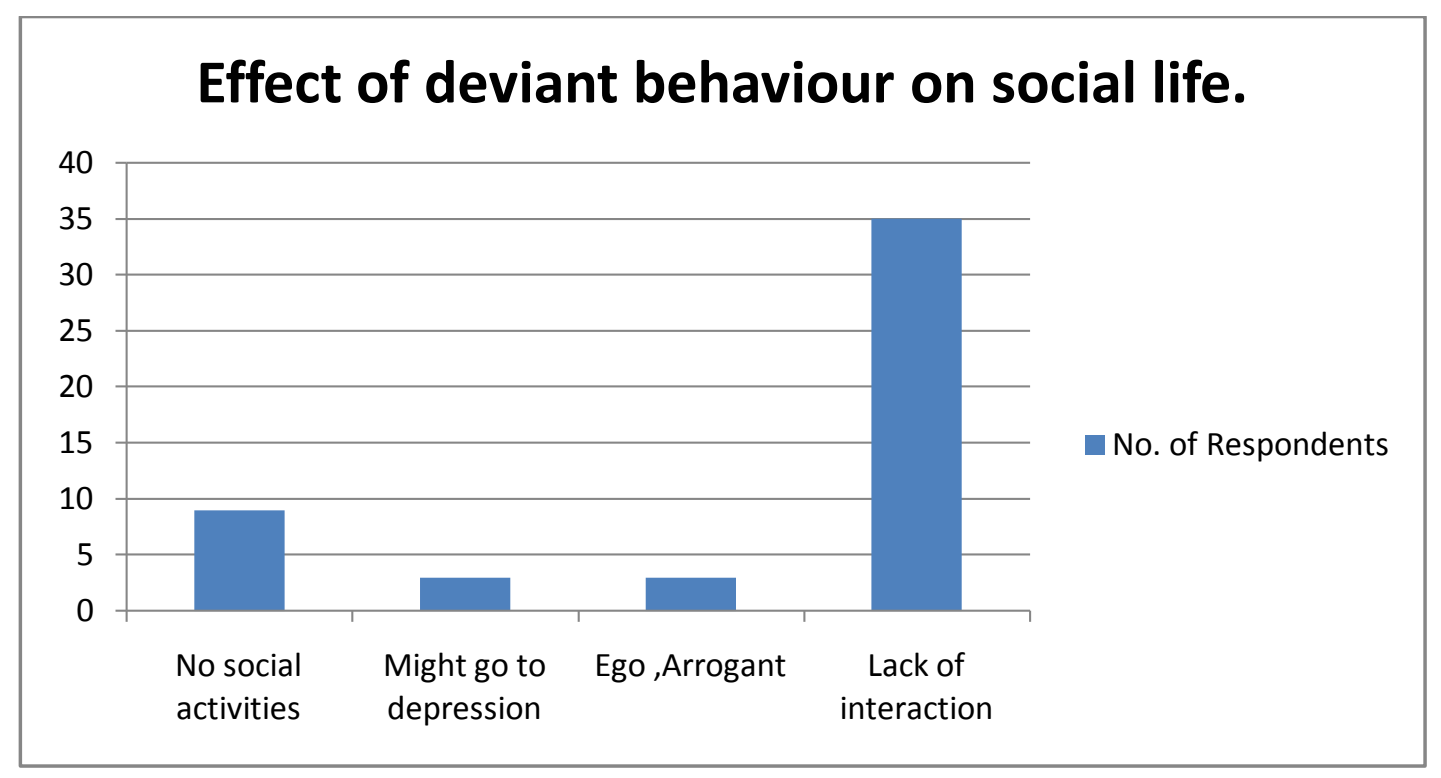

Table No: 7. Showing the distribution of impact on family members.

\begin{tabular}{|c|l|c|c|}
\hline Sl.no & Impact on family members & No. of Respondents & Percentage \\
\hline 1 & Won’t accept the kid & 4 & $8 \%$ \\
\hline 2 & Reputation might go down & 5 & $10 \%$ \\
\hline 3 & Family education & 1 & $2 \%$ \\
\hline 4 & Loose everyone & 7 & $14 \%$ \\
\hline 5 & Siblings might follow & 4 & $8 \%$ \\
\hline 6 & No peace of mind & 29 & $58 \%$ \\
\hline \multicolumn{2}{|l|}{ Total } & 50 & 100 \\
\hline
\end{tabular}

According to the above table $58 \%$ of the family members among the population won't have peace of mind $10 \%$ of the family reputation will go down ,family won't be educated, they might lose everyone, siblings might follow them $2 \%, 14 \%, 8 \%$ respectively 
Teachers' Perception about Students Indulging in Deviant Behaviour

Table No.8: Showing the distribution for societies reaction.

\begin{tabular}{|c|l|c|c|}
\hline Sl.no & Societies reaction & No. of Respondents & Percentage \\
\hline 1 & Ignorance & 25 & $50 \%$ \\
\hline 2 & Punishing & 21 & $42 \%$ \\
\hline 3 & No respect & 2 & $4 \%$ \\
\hline 4 & Encouragement & 1 & $2 \%$ \\
\hline \multicolumn{2}{r}{ Total } & 50 & 100 \\
\hline
\end{tabular}

According to the above table $50 \%$ of the society will ignore them, few of them will punish won't give respect and encourage them too- $42 \%, 4 \%, 2 \%$ respectively.

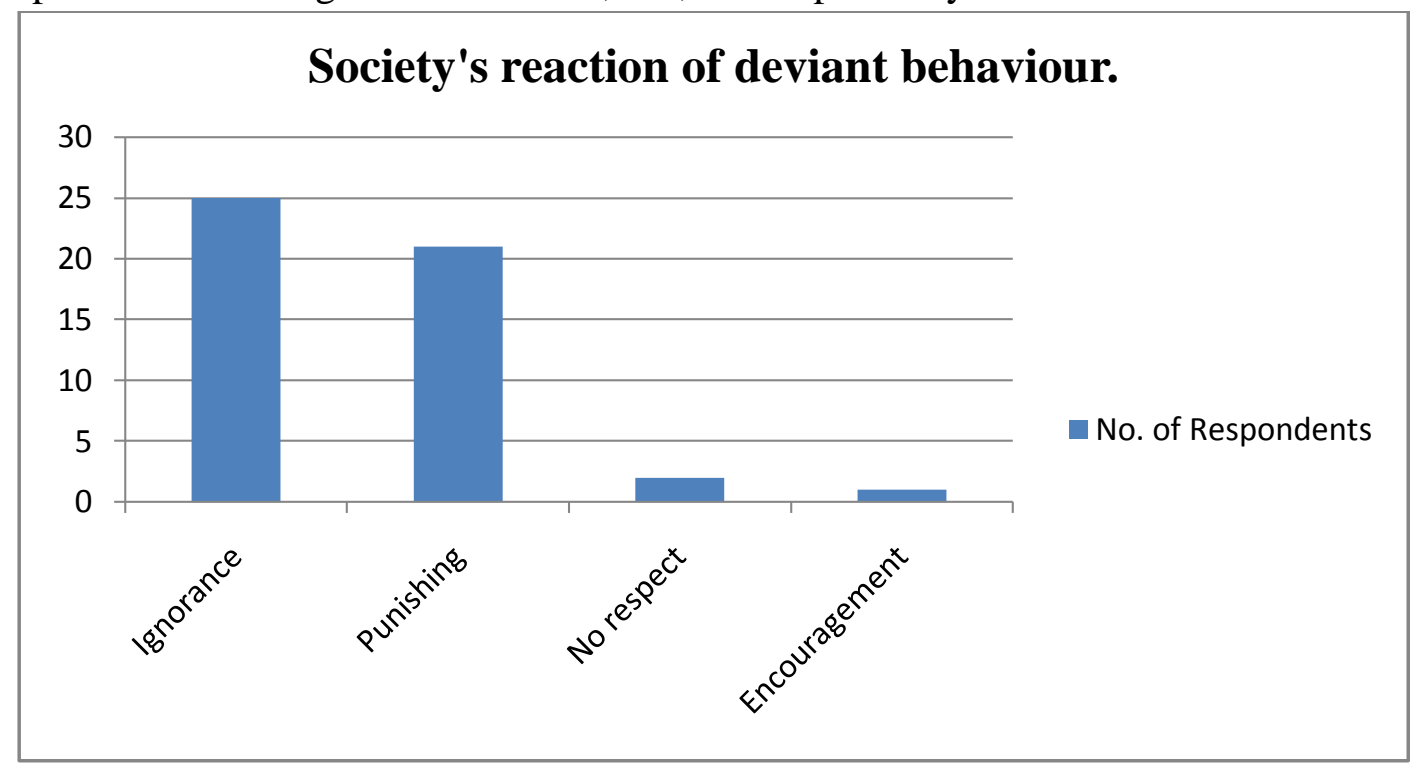

Table No .9: Showing the distribution of prevention of deviant behavior from parents.

\begin{tabular}{|c|l|c|c|}
\hline Sl.no & Parents role & No. of Respondents & Percentage \\
\hline 1 & Understanding the child well & 40 & $80 \%$ \\
\hline 2 & Parents should be strict & 7 & $14 \%$ \\
\hline 3 & Not giving much comfort & 2 & $4 \%$ \\
\hline 4 & Teaching the child to be honest & 1 & $2 \%$ \\
\hline & Total & 50 & 100 \\
\hline
\end{tabular}

According to the table shown below $80 \%$ of the parents among the population should understand the child well ,parents should be strict, they should not give much comfort and they should teach the child to be honest $14 \%, 4 \%, 2 \%$ respectively. 
Table No. 10: Showing the distribution to bring the child on the right track.

\begin{tabular}{|c|l|c|c|}
\hline Sl.no & Back on right track & No. of Respondents & Percentage \\
\hline 1 & Counseling & 47 & $94 \%$ \\
\hline 2 & Parents should give more attention & 3 & $6 \%$ \\
\hline \multicolumn{2}{|c|}{ Total } & 50 & 100 \\
\hline
\end{tabular}

According to the above table counseling and parents should give more attention to bring the child in the right track $94 \%, 6 \%$ respectively.

\section{Findings}

1. Personal Profile of the Respondents

- It was found that majority of the respondents i.e. $54 \%$ were of age $34-44$ years, and $22 \%$ were of 45 -54 years and the reaming were of 25-34 and 55-65 years.

- $50 \%$ of the respondents' qualifications were Masters B.ED and $40 \%$ were Bachelors B.ED and the remaining were B.Sc-M.Sc, B.com. Thus showing that the teachers who are the respondents were qualified and have studied child psychology in their B.Ed. programme.

- $58 \%$ of the respondents teaching experience were between 10-19 years, 28\% was from 19 years and the reaming was from 20-29 years. This shows that the majorities of the respondents has good experience in the field of teaching and subsequently have been around the students more.

\section{Respondents general opinion of deviant behaviour among students}

- From the data collected and the table it can be said that $96 \%$ of the respondents are of the opinion that school students are indulging in deviant behaviour, and the rest fell that there is no indulgence in deviant behaviour among the students.

- Similarly it can be seen from table that $76 \%$ of the students between the age limit of 12 15 years will indulge in deviant behaviour and the remaining $24 \%$ will be either between 8-12 years or 15-17 years.

- $64 \%$ of the deviant behaviour is seen among boys, $6 \%$ of deviant behaviour is seen among girls and the remaining $30 \%$ is seen among both girls and boy.

- $28 \%$ of deviant behaviour which is seen among students is disobeying elders, $20 \%$ is stealing, $16 \%$ is fighting, $12 \%$ is drug abuse and remaining $6 \%$ is bunking classes.

- $40 \%$ of deviant behaviour is caused due to improper parenting style, $26 \%$ is due to family background, $22 \%$ is due to the influence of media, and remaining $12 \%$ is due to the friends circle and the surrounding.

Therefore deviant behaviour is seen in school students of age between 12- 15 years and it is mostly seen in boys. Some of the deviant behaviour which is seen among school students is disobeying elders, fighting, and stealing and drug abuse. According to the teachers opinion the 
main factors for the students indulging in deviant behaviour are neglected parenting style, family background which includes poverty, friends circle and school surroundings and getting influenced by the media.

\section{Respondents Perception on effects of such students}

- $48 \%$ of students get distracted, $26 \%$ of students won't have goal in their life, and the remaining students may get into antisocial activities, might even develop inferiority complex.

- $\quad 98 \%$ of students will have impact on studies and the remaining $2 \%$ of students won't have impact on studies.

- $48 \%$ of students will get low marks in exams, $30 \%$ of students may dropout from school and the remaining students might get distracted and become careless.

- $58 \%$ of the families the members won't have peace of mind the reputation the family members will come down.

- $50 \%$ of the society members will ignore these deviant students, $42 \%$ of the people punish them and the reaming people won't respect them.

Therefore the students who indulge in deviant activities will gradually loose interest in studies and sometimes they might even drop out from school the family members will lose the reputation and the society won't give them any kind of respect.

\section{Respondents way of preventing deviant behaviour}

- $80 \%$ parents should understand the child well, 14\%parents should be very strict and they shouldn't give much comfort to the child.

- $84 \%$ counseling should be done in school and class level.

Parents should become strict and they should not give much comfort to them. Parents should regularly have contact with the teachers and teacher5s should inform parents if there is any problem with the student and both parents and teachers should give proper cancelling to the child so that the child won't get into any deviant activities.

\section{CONCLUSION}

From the study made, it was found out that $96 \%$ of the school students will indulge in deviant behaviour according to the respondents. The mostly seen deviant behaviour are disobeying elders, stealing and fighting these kind of deviant behaviour is seen among boys but sometimes both in girls and boys. But most of the kids who indulge in deviant behaviour later wont indulge in crime if they indulge in crime they might commit crime like robbery, sexual assault and cybercrime. 
The main factors for the students to indulge in deviant behaviour are:

1. Improper parenting style

2. Family background

3. Friends circle and surrounding

4. Media

Parents are the first teachers they should teach the kid to be honest and they should teach them the value of life. They should not be too strict they should show love and care to the child. It is the duty of parents to have a check on the child's friends and their school background.

The students who indulge in deviant behaviour won't mingle or interact with other students, sometimes they might even go to depression. The teachers should regularly talk with the students and make them indulge in other kind of activities so that their mind won't be diverted to other kind of activities. There should be moral educational classes which should be held in classes so that the kids will learn moral values.

The society should treat those kids equally they shouldn't not compare the kids. Instead of punishing the kids few websites should be banned to the kids and proper verifications regarding the age should be done before registration into any kind of social media. Tobaccos and other kind of drugs should be banned in the school surroundings. Councilling centres should be opened. Proper advice and cancelling will help the child to bring the child no the right track.

\section{Suggestions}

Therefore the main suggestions that the parents and teachers should follow to bring the child back on the right track are,

1. More care, love and attention should be given to the child.

2. Parents should not give much comfort and they should not be too strict.

3. In schools moral education classes should be held so that children's will learn moral values.

4. Parents and teachers should encourage child's talent other than studies

5. Proper advice and counselling from parents and teachers will bring the child on the right track.

\section{Acknowledgments}

The author appreciates all those who participated in the study and helped to facilitate the research process.

Conflict of Interests: The author declared no conflict of interests. 


\section{REFERENCES}

B R Sharma Fourth Edition Universal Law Publishing Co- Forensic Science in Criminal investigation and Trial

Carol Hayden, Institute Of Criminal Justice Studies, University Of Portsmouth, International Journal of Violence and School - 9 - September 2009 deviance and violence in schools a review of the evidence in England.

Jaonan Cheng, Associate Professor Department of Education, National Taitung University, Taiwan, The Journal of Human Resource and Adult Learning, Vol. 8, Num. 2, December 2012, The Effect Factor for Students' Deviant Behavior J

Siegel Tenth, Edition-Criminology Theories, Patterns, and Typologies Wayne A. Petherick, Brent E. Turvey, Claire E.Fergunson-Forensic Criminology.

\section{Website}

Academic performance of secondary school students, Retrieved from

https://eduresearchhome.wordpress.com/deviant-behaviour-and-academic-performanceof-secondary-school-student/

Criminology theories (2014) Tania Retrieved from (April 22,2014)

https://blog.udemy.com/criminology-theories/

Deviant behaviour in school students (2010) Rawle Welch Retrieved from (Feb 19,2010) http://www.kaieteurnewsonline.com/2010/02/19/deviant-behaviour-in-our-schools/

Deviant behaviour in teenagers (2014) Eunice M. Nyamoko Retrieved from (Sep-Oct 2014)

http://www.slideshare.net/novelty3/causes-of-deviant-behaviour-in-teenagers

Deviant behavior, Retrieved from http://definitions.uslegal.com/d/deviant-behavior/

Factors influencing deviant behavior (2012) Njoroge Samuel Maina Retrieved from (2012)http://ir-library.ku.ac.ke/handle/123456789/2277?show=full

History of criminology and theories, Retrieved from http://study.com/academy/lesson/what-iscriminology-definition-history-theories.html

Relationship between deviance and crime, Retrieved from https://quizlet.com/12848182/ch-7deviance-and-crime-key-concepts-flash-cards/

How to cite this article: Jayaam B, Caeiro D (2017), Teachers' Perception about Students Indulging in Deviant Behaviour, International Journal of Indian Psychology, Volume 4, Issue 2, No. 93, ISSN:2348-5396 (e), ISSN:2349-3429 (p), DIP:18.01.130/20170402, ISBN:978-1-36578193-3 